\title{
El matrimonio como sacramento cristiano: un aporte de Balthasar para los tiempos del sínodo*
}

\author{
Nelson Jair Cardona Ramírez
}

Recibido: 19 de noviembre 2014 • Aprobado: 19 de enero 2015

\section{Resumen}

El matrimonio como sacramento cristiano no puede entenderse como un simple instituto natural al que se otorga una bendición. Como sacramento de la Nueva Alianza que es, debe fundarse en el acontecimiento redentor de Cristo, quien desde el misterio de la cruz arroja una luz nueva sobre todas las realidades vitales del discípulo.

Entrega, fidelidad, unidad, sexo, fecundidad, pobreza, castidad, obediencia, según el teólogo Balthasar, han sido plenificadas y cualificadas por el acontecimiento del Cristo Esposo, que en una cruz se ha entregado por la Iglesia Esposa. Una entrega tal es la que funda el sacramento del matrimonio y no meramente el acto social por el que un hombre y una mujer se entregan mutuamente.

Palabras clave: Matrimonio, sacramento, esposo, esposa, fidelidad, fecundidad.

* Producto de las investigaciones del autor.

* Presbítero de la diócesis de La Dorada-Guaduas; Licenciado en Teología Espiritual por la Universidad Gregoriana de Roma, Doctor en Teología por la UPB-ITEPAL; Profesor de Teología en el Seminario Mayor Cristo Buen Pastor de La Dorada-Guaduas, Colombia.. Catedrático del ITEPAL. Correo electrónico: njaircr@hotmail.com 


\title{
Marriage as a Christian sacrament: A contribution of Balthasar in times of the synod
}

\begin{abstract}
The marriage like Christian sacrament cannot be understood like as a natural institute to which a blessing is granted. As a sacrament of the New Alliance that is should be founded in Christ's redeeming event who throws a new light, all vital realities from the disciple. Donation, fidelity, unit, sex, fecundity, poverty, chastity, obedience, according to the theologian Balthasar, have been fully and qualified by Christ Husband who has surrendered in a cross for the Church his Wife. Such delivery is the one that founds the marriage sacrament and not merely the social act for which a man and a woman have been donated mutually.
\end{abstract}

Keywords: marriage, sacrament, husband, wife, fidelity, fecundity.

\section{Le Mariage en tant que Sacrement Chrétien: Un apport de Balthasar pour les temps du synode}

\section{Résumé}

Le mariage en tant que sacrement chrétien, ne peut être conçu comme un simple instinct naturel auquel une bénédiction est accordée. En tant que sacrement de la Nouvelle Alliance, il doit se fonder sur l'évènement rédempteur du Christ, qui depuis le mystère de la croix, fait apparaître une nouvelle lumière sur toutes les réalités vitales du disciple.

Se donner, fidélité, unité, sexe, fécondité, pauvreté, chasteté, obéissance, selon le théologien Balthasar, ont été planifiées et qualifiées par l'évènement du Christ époux, qui s'est donné sur la croix pour l'Eglise épouse. Se donner de telle façon est le fondement du sacrement du mariage et non simplement l'acte social par lequel un homme et une femme se donnent mutuellement.

Mots-clés: Mariage, sacrement, epoux, epouse, fidélité, fécondité. 


\section{Introducción}

Los acontecimientos de la encarnación, la pasión y la resurrección del Hijo de Dios han aportado un nuevo modo de ser a los discípulos, a tal punto de que el seguimiento de Cristo ha dado un nuevo sentido y un nuevo horizonte a toda la vida del cristiano. Después de Cristo la vida, la muerte, el sacerdocio, el trabajo, las relaciones humanas, el matrimonio, el sexo, los hijos... han sido bañados con una luz nueva que no permite verlos como eran antes, sino que han recibido características y medidas nuevas.

Con motivo de las actuales conversaciones al interior de la Iglesia sobre el matrimonio y la familia, se han tejido muchas expectativas, conjeturas y malinterpretaciones. Por eso se hace necesario comprender, cuál es la nueva cualidad, la nueva exigencia, la nueva medida que pone el sacramento del matrimonio a la unión natural entre el hombre y la mujer. Seguramente los grandes teólogos han hecho sus aportes al tema, pero nos limitaremos aquí a indagar y sistematizar en la obra teológica de Hans Urs Von Balthasar el pensamiento acerca de la sacramentalidad, referencia al matrimonio de los orígenes, fidelidad, indisolubilidad, unidad y vivencia evangélica del matrimonio entre cristianos católicos. Serán de gran provecho después de los debates del sínodo extraordinario del 2014 y a la espera del sínodo general del 2015, dedicados a la familia.

\section{La sacramentalidad del matrimonio}

La anatomía del hombre y de la mujer, la complementariedad mutua, la fecundidad proveniente de su unión, la importancia que como pareja tienen para el bien social, etc., aparecen tan evidentes a los ojos de los hombres, que el matrimonio viene entendido, no pocas veces, como una institución de carácter natural. Tal pensamiento, ampliamente difundido, puede hacer caer en la tentación de tomar como punto de partida, para explicar la sacramentalidad del matrimonio cristiano, el hecho de que sea ante todo un instituto natural. Un punto de partida tal, desembocaría consecuentemente en considerar el matrimonio como una especie de bendición sobrenatural otorgada como sobreañadido (Balthasar, 1964), o llevar también a explicar el sacramento en cuestión, como una "elevación" al plano de la Gracia, mediante el sacramento, de una institución de carácter natural (Balthasar, 1994).

En el matrimonio, no puede ser el acontecimiento humano de la alianza entre hombre y mujer lo que especifique la gracia (Balthasar, 1985a). Para que sea en 
verdad un sacramento cristiano de la Nueva Alianza, tendrá que ser interpretado en principio desde arriba, desde el acto que lo funda como matrimonio cristiano y le concede la especificidad de su Gracia.

Si no es el hecho sociológico, ¿cuál de los acontecimientos de la vida de Jesús es, entonces, el que especifica, funda y justifica la gracia en el sacramento del matrimonio? La respuesta es dada por San Pablo:

Maridos, amen a sus mujeres igual que el Mesías demostró su amor a la Iglesia entregándose por ella: quiso así consagrarla con su palabra, lavándola en el baño del agua, para preparase una Iglesia radiante, sin mancha ni arruga ni nada parecido, una Iglesia santa e inmaculada. Así deben también los maridos amar a sus mujeres como a su propio cuerpo. Amar a su mujer es amarse a sí mismo; y nadie ha odiado nunca a su propio cuerpo; al contrario, lo alimenta y lo cuida, como hace el Mesías con la Iglesia, porque somos miembros de su cuerpo. 'Por eso dejará el hombre a su padre y a su madre, se unirá a su mujer y serán los dos un sólo ser'. Este símbolo es magnífico; yo lo estoy aplicando a Cristo y a la Iglesia; pero también ustedes, cada uno en particular, debe amar a su mujer como a sí mismo, y la mujer debe respetar al marido. (Efesios 5, 25-33).

Pablo se vale de la imagen de los desposorios de Cristo con su Iglesia para hablar del matrimonio entre cristianos; pero tal comparación podría tener solo un carácter metafórico, que cualquier persona con mediano ingenio podría acomodar sin mayores esfuerzos. Si así fuera, es claro que la doctrina sobre el Matrimonio como sacramento de la Nueva Alianza no podría sostenerse sin grave perjuicio. Para que tal imagen sea en realidad el punto focal, desde el cual se pueda entender la sacramentalidad del matrimonio de la Nueva Alianza, ella debe gozar de una objetividad real y no simplemente simbólica.

En el campo de la existencia intramundana, para que exista un verdadero matrimonio son necesarias tres cosas: en primer lugar, dos personas, que aún cuando se unan sexualmente permanezcan siempre inconfusas; en segundo lugar una unión que les permita ser "una sola carne", de la que es prueba tangible la aparición de los hijos y en tercer lugar, es necesaria una oposición física de sexos. Solo si a la relación de Cristo con la Iglesia le caben tales características, podrá ser considerada como el arquetipo del matrimonio cristiano.

Respecto a la primera línea de semejanza, que alude a la singularidad de los miembros de la relación, es un hecho que Cristo es una persona real, con una corporalidad concreta y una sexualidad definida, y es presentado en el Nuevo 
Testamento como el Esposo. En cambio, no sucede lo mismo cuando se trata de la Iglesia, quien a primera vista aparece como un colectivo que, aunque de especiales características, sigue siendo de todos modos un colectivo. Han sido los Padres de la Iglesia quienes la han presentado como un verdadero sujeto, del que se puede describir su belleza, sus sentimientos, sus pensamientos, etc. A una tal concepción de la Iglesia contribuyó fuertemente el paralelismo entre Iglesia y María. Es a tal paralelismo al que Balthasar se aferra fuertemente para demostrar que la Iglesia es, ante todo, una persona. En efecto, la Iglesia-Esposa, quizás no suficientemente concebible como persona en el sentido estricto del término, aparece en cierto modo personificada en María, quien a su vez cristaliza a su alrededor la totalidad de los creyentes y esto, sobre todo, desde el acontecimiento de la cruz, donde su donación viene universalizada.

María y la Iglesia se identifican en muchas cosas: Son fe que ama y espera en actitud femenina, son seno fecundo de la Palabra en una doble dimensión: pasivamente en cuanto que reciben el Verbo y activamente, en cuanto continuamente lo engendran en sí y en los creyentes, ambas realizan su fecundidad en la dimensión del eros divino, son culmen de la fecundidad de la primera "madre de los vivientes" y todas dos gozan de una virginidad recibida y aceptada (Balthasar, 1985b). "Cristo quería una Iglesia sin mancha ni arruga y si nos preguntamos, dónde la Iglesia corresponde plenamente a este ideal, entones una vez más somos enviados a la Inmaculada y nosotros sabemos que María ha adquirido esta cualidad, desde la cruz del Hijo" (Balthasar, 1991b, p 119). El sujeto eclesial se halla, pues, incoativamente presente en su célula primigenia en María (y Juan con ella) (Balthasar, 1988b), en su "sí" están presentes todos los "sí" de la Iglesia, y su fundamental y objetiva aceptación de la voluntad de Dios envuelve y supera los "no" que los miembros individuales de la Iglesia pronuncian frente a la voluntad del Padre. Por eso ella, en cuanto cumple su misión personal en la entrega del Hijo, puede ser llamada también el centro personal de la Iglesia (Balthasar, 1993).

$\mathrm{Al}$ aceptar por tanto que la Iglesia -entendida en clave Mariana-, en una manera "sobrenatural" es persona y Esposa, y que como tal es un sujeto diferenciado, se puede establecer la segunda línea de semejanza: Cristo Esposo, que es también Cabeza, y la Iglesia Esposa, que es también cuerpo $(\mathrm{Col} 1,18)$, pueden realizar una unión tal que los haga "una sola carne" y que sea, consecuentemente, fecunda.

Cuando Balthasar habla de corporeidad de la Iglesia, afirma que también en esta dimensión se encuentra la categoría del misterio, y que éste solo puede ser abordado si se presupone el misterio de la Eucaristía, pues en ambos misterios la corporalidad es sobrenatural, establecida a partir de Cristo. La unión, por tanto, no puede ser entendida en categorías meramente biológicas, pues Cristo no 
proviene del paraíso, sino del cielo y su cónyuge ha recibido existencia a partir de su sustancia (no de la misma manera que Eva, quien gozaba de personalidad propia independientemente de Adán, pues la Iglesia debe su personalidad a Cristo y no puede ser concebida independientemente de Él). La unión de esta pareja singular, no se realiza en el bios, sino en el Logos y en el Pneuma, y así, el misterio de la única carne queda efectuado en su más sublime expresión (Balthasar, 1985b). En efecto, no se trata ya de la emisión del semen masculino en el órgano genital femenino, sino de la sobrenatural unión que Cristo ha hecho posible en la Eucaristía: la absoluta y envolvente compenetración del Esposo y de la Esposa en un amor puro y entregado que tiene como consecuencia el surgimiento a la Nueva Vida en Cristo.

En la tercera línea, la de la oposición de los sexos, es claro que la Iglesia, a pesar de realizar también la imagen del cuerpo, (siempre dentro de las categorías del misterio) no puede considerarse como fusionada con Cristo. No puede decirse que ella sea Cristo (El elemento masculino de la unión), en el sentido de considerarla como hipostáticamente unida con Dios que habita en ella. La Iglesia, aunque recibe su existencia de Cristo y no puede pensarse sin Él, sigue siendo la "otra" parte de la pareja, la parte femenina y vive por tanto en actitud de recepción, en el modo Mariano (Balthasar, 1991a).

En los tres aspectos anteriores Matrimonio humano y Matrimonio entre Cristo y la Iglesia se identifican y por eso el segundo puede ser causa de la sacramentalidad del primero.

\section{La referencia al Matrimonio de los Orígenes}

El Matrimonio, como sacramento cristiano existe solo a partir de Cristo; pero es una evidencia bíblica que ya desde el Génesis existe el matrimonio como forma de vida y que permaneció aún después de la caída. Es válida entonces la pregunta sobre la relación existente entre el matrimonio de los orígenes y el matrimonio de la Nueva Alianza, pues sería ilícito pensar que quien ha venido a consumar y dar plenitud a todas las cosas, hubiera dejado de lado la larga historia de salvación en que el matrimonio estaba inscrita.

Es innegable que el Génesis presenta a la primera pareja humana con evidentes características matrimoniales: Adán y Eva han sido creados el uno a partir del otro y, aunque poseen diversas características sexuales, pueden concebirse solo como "unidad dual" (Balthasar, 1992a), de hecho, según el relato, forman "una sola carne" y mediante ello pueden realizar, como pareja, el fundamental 
mandato de multiplicarse, acto para el cual han sido dotados por Dios de una fecundidad que es a la vez espiritual y biológica.

En su obra Estados de Vida del Cristiano (1994) el teólogo suizo, a partir de tres características fundamentales contempla el matrimonio de los orígenes: obediencia, virginidad y pobreza. Tales características, impensables la una sin la otra, son el eje en torno al cual gira toda la vida de la pareja primigenia.

La característica preponderante de su existencia paradisiaca y de la que las otras dos reciben su existencia es la obediencia al Creador. De ella depende que hombre y mujer puedan dominar sobre las criaturas, pues está inscrita en un círculo lógico: hombre y mujer obedientes a Dios y por ello la creación obediente a ellos. Tal obediencia es una exigencia tan obvia para el hombre, que no necesita reflexión alguna para llevarla a cumplimiento, es más, únicamente en el cumplimiento de tal obediencia, que es ante todo fe -entendida ésta como fundamental confianza y entrega en el Señor-, el hombre y la mujer se sienten inmensa y realmente libres, de manera que no viven por debajo de las exigencias éticas, sino que las sobrepasan.

La segunda característica es la virginidad. Es cierto que ya antes de la caída Adán y Eva vivían como marido y mujer, pues habían recibido desde el comienzo la orden de crecer y multiplicarse, pero en el paraíso las fuerzas naturales del hombre están envueltas por el acto fundamental de obediencia creyente; el alma es la que envuelve el cuerpo, como lo pequeño es envuelto por lo dominante, de manera que; aunque el deseo está ya presentes en el hombre, éste es solo servidor del amor y no su patrón. La pureza del alma irradia de tal manera sobre el cuerpo, que éste es absolutamente casto. En él no hay lugar a la concupiscencia mala, pues reina la convicción de que el amor verdadero tiene ante todo su centro en el espíritu y que el cuerpo es solo su campo de expresión. Dentro de esta síntesis paradisiaca, fertilidad y virginidad no se contraponen, el amor, envuelto en la gracia habría sacado del espíritu la salida a su fertilidad y habría incluido en su casta pureza al cuerpo solo como servidor.

La tercera característica del matrimonio primigenio es la pobreza. En el paraíso el hombre, sin vivir en la indigencia, puede ser completamente pobre. La vida en el Edén es una vida en la plenitud de la gracia proveniente del cielo, allí esposo y esposa reciben todo, o bien directamente de la mano de Dios o bien mediatamente, a través de la naturaleza, que expresa su respuesta generosa a la Gracia con la exuberancia de sus frutos. Así pues, viven a un tiempo la riqueza completa y la pobreza perfecta, pues todo lo tienen, no como posesión o pago de sus esfuerzos, sino como donación pura de Dios. Al no conocer ni necesidad, ni 
indigencia alguna, no necesitan para sí nada que tengan que esconder o escatimar el uno al otro.

La pareja del paraíso está dispuesta a elegir pobreza, virginidad y obediencia, sin que tales actitudes encierren para ella la más mínima significación de renuncia o sacrificio, ellas son, por el contrario, la expresión de un amor que pone en sí toda riqueza, toda bendición, toda plenitud.

\section{Matrimonio y caída}

El enemigo de la realización de la obra de Dios, piensa Balthasar (1994), simbolizado en el texto del Génesis como la serpiente, usa la mentira para inducir en la mente de aquellos primeros hombres la convicción de que la obediencia, en la que hasta ahora habían permanecido fieles, no es más que una treta de Dios para impedir el acceso a posibilidades más altas, y hace que la libertad de la obediencia aparezca como privación del poder soberano sobre toda criatura. El hombre y la mujer se dejan seducir y rompiendo así la fe obediente en Dios, sacan a la luz la razón desnuda, una razón sin fe. Se les abren los ojos y llegan a saber lo que Dios sabe; pero que sabiamente había querido ocultarles: La distinción entre el bien y el mal (Cfr. Gn 3, 7).

Con una emancipación tal de la voluntad divina, todas las fuerzas psíquicas que antes, aunque presentes, eran envueltas por lo espiritual, emergen desnudas de su envoltura de gracia y la vergüenza toma el puesto de lo que hasta ahora fuera inocencia; las capacidades corporales se desvinculan de la fertilidad del amor y se adueñan del poder en el amor sexual trastocando así el orden original. Surge entonces la irreparable ruptura entre virginidad y fertilidad y de ahora en adelante la una se opondrá irremediablemente a la otra.

La conciencia de su desnudez hace venir también abajo la fundamental pobreza que los caracterizaba. Al darse cuenta de que estaban desnudos comenzaron a tejerse delantales, cada uno el suyo (Cfr. Gn 3, 7), estableciendo con ello el comienzo de la propiedad privada. Así como por la obediencia a Dios la naturaleza era obediente a ellos, ahora, de igual manera, su desobediencia arrastra consigo la rebeldía de la naturaleza. De ahora en adelante todo se hace escaso y comienza la lucha por la existencia, haciéndose inevitable la penosa necesidad de la propiedad privada y el odioso concepto de lo tuyo y de lo mío. Es más, aún la relación entre los sexos se verá enmarcada en una lucha por el dominio y posesión del otro (Cfr. Gn 3, 16). 
La criatura se ha soltado de Dios y ha convertido en meta lo que debería ser medio, por tanto, también la finitud se vuelve desnuda hacia afuera: La vida terrena que no está ya envuelta en la vida eterna, queda amurada, sin esperanza alguna, en su finitud, y ese muro es sinónimo de muerte. Ahora, aunque la pareja lo desee con todas las fuerzas no podrá más, por propia decisión, retornar a aquella dichosa gracia paradisiaca, pues la espada del querubín impide el retorno (Gn 3, 24) (Balthasar, 1988a).

Si las características de la vida paradisiaca estaban indisolublemente unidas la una con la otra, de igual manera lo están los resultados de la caída: la sexualidad ligada con el dolor y la muerte y con la voluntad de propiedad y posesión del otro. La autonomía moral con la libre disposición de los instintos corporales y con la propiedad privada que garantiza tal autonomía y la voluntad de poseer con la voluntad de tener una visión panorámica del bien y del mal, así como de hacer funcionar como cosa propia la fertilidad corporal (Balthasar, 1994).

\section{El matrimonio después de la caída}

No obstante los tristes acontecimientos desencadenados por el primer pecado, la imagen de Dios en el hombre no se pierde. Con este permanecer de la imagen, se mantiene también el matrimonio y su fertilidad, cuya fundación provenía de una acción preternatural de Dios y apuntaba, a la realización renovada sin cesar de la unidad más que natural del amor. Lo natural conserva su origen sobrenatural y por ello también una finalidad sobrenatural a la que el hombre y la mujer tenían que servir en el paraíso y a la que deben seguir sirviendo después del pecado. Dios siguió estando dispuesto a donar la gracia de su fertilidad creadora cada vez que un hombre y una mujer se unieran física y espiritualmente en virtud de aquella bendición de los orígenes (Balthasar, 1994).

Es más, en la Antigua Alianza el matrimonio no sólo permanece, sino que se convierte en normativo. La razón es que la virginidad del paraíso ya no existe. Esto resulta tan claro para Israel que la esterilidad y el celibato -en el excepcional caso que se diera- son vistos, el primero como maldición y luego, en orden a la espera mesiánica, como imposibilidad de participar en la generación del Mesías $\mathrm{y}$, el segundo, como desobediencia del mandato original y como incredulidad respecto a las promesas de Dios (Balthasar, 1988b). 


\section{La obra de Cristo frente al matrimonio}

La expulsión de Adán y Eva habría sido el inicio de un viaje sin retorno, si no les hubiera sido dada una esperanza: La imagen, no sólo del hombre, sino también del matrimonio original podría resplandecer de nuevo solamente cuando la virgen concibiera y diera a luz un hijo (Is 7, 14). Esta virgen, por obra del Altísimo, cumpliría con creces la fertilidad del paraíso, pues daría a luz a Dios mismo, que redimiría de su culpa al mundo (Balthasar, 1994).

Desde este ángulo se comprende mejor el profundo sentido teológico del matrimonio entre María y José, que no solo era necesario para que Jesús fuera tenido como hijo de David, sino también para que el sentido religioso del matrimonio veterotestamentario alcanzara plenitud. Naturalmente lanza su mirada hacia el pasado como obediencia a los profetas y corona de la fecundidad de Abraham pero también, aunque de manera vaga, él cruza los umbrales de la Nueva Alianza y arroja una luz sobre toda la novedad cristiana que dimana de la cruz; esa luz, clarísima en María, la deja transparentar también José, quien supo renunciar desde la fe a la dimensión genital de su matrimonio, participando así de la fecundidad virginal de su mujer (Balthasar, 1988b). Una tal renuncia era, según Balthasar, necesaria, pues Cristo no pudo proceder de una unión de hombre y mujer tal como se practica después de la caída. ¿Cómo podría ser el acto destructor de la esencia virginal de la consorte, el principio de aquel que ha venido a quebrar el poder del pecado? además, tampoco la restauración del estado original y por tanto del matrimonio original podía ser algo mecánico, pues no se trataba solo de una restauración; sino, al mismo tiempo, de vencer la culpa, y esto realizado, no con una intervención externa y positiva de Dios, sino con un acto transformante de la esencia misma del hombre y de la mujer y de su unión marital (Balthasar, 1994).

Restauración y redención se hacen posibles solo porque el nuevo Adán viene de mucho más allá que del paraíso y trae la redención de más arriba, de donde el primero la había recibido. El primer Adán procede del suelo, el segundo del cielo, más concretamente del Padre. Es más, el primer Adán ha sido creado a causa y en vistas del segundo, aunque cronológicamente aquel haya aparecido primero (Balthasar, 1992a y 1991b). Por eso, hablando específicamente del matrimonio debemos decir que Cristo no lo refundó, sino que lo consumó, retornándole de alguna manera la síntesis paradisiaca, y más aún, concediéndole un contenido de gracia que provenía del misterio de Dios, mucho más profundamente que el del matrimonio de los orígenes. Es que Cristo no se limitó a enviar gracia sobre lo terreno, como si se tratará de cubrir con una capa de santidad lo que intrínsecamente continuará siendo malo, sino que viene como gracia de Dios 
hecha hombre, como cielo hecho tierra que puede transformar en su esencia las realidades terrenas. Precisamente por esto somos criaturas nuevas pues Cristo ha llevado a cabo una síntesis muy superior a la paradisiaca.

El matrimonio que gozaba de una sobrenaturalidad general por la bendición de los orígenes, recibe así, en la Nueva Alianza, una sobrenaturalidad concreta, conformada de la gracia de Cristo en la Cruz, que es la expresión más alta de su amor: amó a la Iglesia y se entregó por ella hasta el extremo de dar la vida. Desde el momento en que Cristo ha realizado una obra tal, ya no es posible para el cristiano regirse por un modelo diverso a éste; por eso nos recuerda Juan las palabras del Señor: "Este es el mandamiento mío: que se amen unos a otros como yo los he amado" (Jn 15, 12), así, también el amor conyugal debe, si quiere ser en realidad cristiano, acoger esta nueva medida y participar con Cristo del sacrificio. La Gracia recibida de la cruz, a la vez que transforma el amor humano en ágape, libera al matrimonio primitivo de su pequeña y limitada fertilidad, dándole la fertilidad católico-eucarística, del amor redentor de la Palabra hecha carne y del amor redimido de su novia y consorte, de la Iglesia, que es el al mismo tiempo su cuerpo (Balthasar, 1994).

Tal fecundidad natural, ahora transformada, se convierte en parábola intramundana de una fecundidad incomparable, aquella espiritual: de fe, esperanza y caridad, que arrastran consigo el espíritu de obediencia, castidad y pobreza, tal como ellas han sido recuperadas y elevadas en Cristo; esto es, marcadas con el signo de la muerte-ágape del nuevo Adán por la nueva Eva (Balthasar, 1992a).

Es la Nueva alianza la que arroja sobre la relación conyugal su gracia concreta. La relación hombre y mujer deja de ser simplemente una imagen para la relación de Dios con la humanidad o con el pueblo, como lo fue en los tiempos de la Antigua Alianza y pasa a sumergirse en la zona de la gloria, convirtiéndose, en cuanto relación encarnada del Cristo Esposo con la Iglesia Esposa, en el culmen de la relación interna de los sexos y de lo que tal relación supone y conlleva (Balthasar, 1988a).

\section{El matrimonio cristiano bajo el sello del Espíritu Santo}

Según Von Balthasar, el Espíritu Santo en la Iglesia, actúa en dos dimensiones: En primer lugar, es objetivo, es Persona del Amor y testigo del amor que se nos ha regalado. En este sentido es el responsable de la actualización del sacramento del matrimonio e infunde en la pareja que se casa la vida del Cristo Esposo que se 
autodona a la Iglesia Esposa, llenando al marido y a la mujer de la irrepetibilidad e historicidad de ese acto originario.

La segunda dimensión del Espíritu es la subjetiva, por ella es Espíritu que inspira al cristiano el camino justo para realizar el designio de Dios sobre él, impulsándolo a optar, si es el caso, por la vida matrimonial; iluminándolo en la elección del que es "carne de su carne y hueso de sus huesos" (Gn 2, 23), invitando a los esposos a guardar una obediencia amorosa hacia al Padre. En esa dimensión subjetiva es Espíritu que se nos regala y que puede por eso preparar desde dentro a cada uno de los contrayentes para recibir la vida divina derramada en el sacramento, y les permite, por imposible que parezca, reproducir en sus vidas el amor de Cristo por la Iglesia, moviéndolos a responder, con lo que son capaces, al inmenso don recibido (Balthasar, 1979).

En la actualización del sacramento el Espíritu Santo realiza, según Balthasar (1992b), tres acciones fundamentales:

En primer lugar, ejerce una transformación del eros característico de la vida sexual humana. En adelante éste será ante todo ágape que viene de Dios. No se trata aquí de una eliminación del primero, sino de un enriquecimiento de sentido, que lo pone al servicio del ágape.

En segundo lugar, convierte el amor subjetivo y limitado de la pareja, al igual que su propia fecundidad, en un amor objetivo, un amor en el Espíritu, tal como se realiza entre Cristo y la Iglesia.

Finalmente, realiza una desapropiación total en favor de la pareja, realizando una verdadera pérdida de sí en favor del otro, por amor.

Por todo esto, conviene hablar en el matrimonio cristiano de una manera más directa, de una real inhabitación del Espíritu, pues ágape es el nombre propio del Espíritu Santo y puesto que Cristo concedió al matrimonio la sacramentalidad de la Nueva alianza, éste no puede regirse más que por las leyes del ágape, por la norma de un amor que se pone más allá del utilitarismo, de la concupiscencia mala y de las estrecheces humanas, pues es el amor mismo de Dios derramado en la totalidad de la persona de los contrayentes, por el Espíritu Santo.

\section{Exigencias existenciales del matrimonio cristiano}

\subsection{Fidelidad e indisolubilidad}

En Jesucristo se han realizado las bodas de Dios con la humanidad, que habían sido representadas de diversas maneras en el Antiguo Testamento. El esplendor 
y la fidelidad de Dios adquieren su forma y nombre concreto en Cristo, quien representa la Gloria de Dios y es el modelo original de toda participación creatural en la gloria (Balthasar, 1989). Esta unión hipostática en Cristo, es el último sello indeleble del pacto de fidelidad que Dios, incondicionalmente, mantuvo por siempre con el pueblo. Es en la extrema fidelidad divina, demostrada en Cristo, bajo cuyo signo se hace toda promesa en la Iglesia y por tanto, también la promesa emitida por los cónyuges el día de sus bodas (Balthasar, 1985b).

El hecho que sea en Jesús en quien ahora los esposos se entregan, hace que las promesas de amor y fidelidad se rijan ahora por el mandamiento nuevo de Jesús: "que se amen como yo los he amado" (Jn 15, 12). Este es el canon para todo amor cristiano y lo es también para la fidelidad conyugal. El "si" del consentimiento matrimonial corresponde ahora con la entrega incondicional, al igual que la del Hijo en la cruz, quien entregó todo: cuerpo y alma, por el Padre y por el mundo. En el "sí" sacramental del matrimonio, el cristiano dona su cuerpo y su alma al consorte, el alma abdica de autodisponer de la propia vida y, por tanto, abdica también del propio cuerpo, y todo esto solo puede hacerlo en Dios, desde la fe en él y en la esperanza de su realizadora fidelidad.

Los cristianos al darse mutuamente en matrimonio realizan un supremo acto de fe y éste halla su fundamento último en Dios. Es Él quien lo conforma, lo acepta y lo devuelve trascendido; Él es el fundamento de la unidad de ambos cónyuges, es el testigo de su vinculación. Es Dios quien en el acto de la fe, dona recíprocamente a los esposos dentro del cristiano acto fundante de la entrega. A él se ofrecen ellos conjuntamente; de él recibe cada uno al otro como regalo de Gracia, de confianza pero a la vez de exigencia cristiana. En efecto, el acto en el que los esposos cristianos se prometen mutua fidelidad es absolutamente inabarcable, y podría decirse hasta temerario, en el sentido en que promete mucho más de lo que las meras fuerzas humanas son capaces de realizar. Aquí, coincide con el acto mismo de la fe, pues de la misma manera que la fe cree más de lo que puede entender y abarcar, justamente porque Dios y su palabra bastan, así el voto matrimonial promete más de lo que la fuerza humana sola sería capaz de aguantar, pero esto lo hace en una esperanza firme, pues sabe que Dios es fiel a sus promesas y que Cristo es incondicionalmente fiel a la Iglesia y regala al creyente la fuerza de su fidelidad. La fidelidad que los contrayentes se prometen recíprocamente es indisoluble, solo porque se asienta sobre la fidelidad de Dios mismo, llevada al extremo en Cristo. En ella adquiere su robustez, su indestructibilidad y eternidad, pues Dios sigue siendo fidelidad aún cuando su consorte humana ha sido infiel (Balthasar, 1994). 


\subsection{Unidad}

Por otra parte, el hombre en la creación acabada es, según el pensamiento teológico de Balthasar (1992a), una "unidad dual", es decir, dos realidades distintas pero inseparables entre sí, de la que la una es plenitud de la otra y están ordenadas hacia una unidad definitiva que no tiene límite. Respecto a aquella concesión dada por Moisés para destruir el vínculo matrimonial, Jesús tiene una posición clara: al comienzo, dice, no era así, pues Dios los creó macho y hembra para ser una sola carne, tal unidad profunda es un efecto de la acción de Dios, y el hombre no debe separar lo que Dios ha unido (Mc 10, 5ss). Si alguna concesión dio Moisés fue a causa de la dureza del corazón. Según la originaria voluntad de Dios, hombre y mujer han sido creados para la unidad y ésta no sólo en la carne, sino también unidad perenne en el espíritu por eso "quien mira a una mujer deseándola, ya ha cometido en su corazón adulterio con ella" (Mt 5, 28). Esta unidad no es en ninguno de los casos el yuxtaponerse de dos libertades, ni es tampoco el hecho de que el cristiano como persona individual venga expropiado en su corporeidad, ni se trata simplemente de la pertenencia del hombre a la mujer y de la mujer al hombre, los cuales pierden todo poder de disponer sobre el propio cuerpo (1 Cor $7,4)$; sino que va a situarse mucho más allá, precisamente en la confluencia del amor (Balthasar, 1972).

En efecto, en el matrimonio cristiano ninguno puede disponer de manera egoísta ni de sí mismo ni del otro; ahora se exigen dos consensos que haciendo uso de su libertad se han autodesposeído. Tal cosa se hace posible solo gracias a un tercer elemento objetivo que se compone de ambas libertades: su voto, su promesa. Balthasar lo llama elemento objetivo porque, aunque es el producto de la unión de dos subjetividades, es una voluntad tal que se pone por encima de ellos y en medio de ellos, de tal manera que ninguno de los dos puede reivindicar para sí la autoría de la unidad surgida. Es realidad objetiva, porque ambos, para poder actuar rectamente en común acuerdo, en su desposeimiento, deben mirar a este producto suyo más que al cónyuge, que en el caso ideal, está siempre listo y a disposición del otro. Este elemento objetivo que es también la realidad inspirante de su amor común, se puede llamar indistintamente el espíritu del pacto del amor y éste, en cuanto institución, está eminentemente más allá de los dos (Balthasar, 1979).

\subsection{Sexualidad y Fecundidad}

Lo que antes parecía impensable, la elevación del eros a la esfera del ágape, se ha hecho ya posible (Balthasar, 1989). La visión fecunda, redentora de la cruz, ha 
venido a ocupar el lugar de la tragedia de los sexos desencadenada por la culpa del hombre, que encerró el placer sexual en un círculo del que no había escapatoria, porque el amor perfecto, conferido en el comienzo a los esposos como principio fundante del matrimonio, era irrecuperable mientras el hombre permaneciera en el ámbito de la culpa. Este círculo trágico es destruido sólo cuando Cristo en la cruz, más allá de la caída en el placer sexual, crea una nueva unidad desde la sobreabundancia de su propio amor: la Iglesia, su Esposa. Sólo mediante esto es posible redimir el matrimonio, aunque la unidad del estado original sea irreproducible, en las formas de la entrega cristiana (Balthasar, 1994).

Lo específico en el matrimonio cristiano ha sido decidido ante una cruz, verdadera y cruenta, donde se supone una encarnación verdadera y, en consecuencia, una verdadera sexualidad humana. En esa cruz el Hijo amado, ha vertido su sangre, en cuanto hombre y Esposo, por su Esposa, y desde luego, mujer y humana. Al pensarse en función de este misterio, la sexualidad humana queda sacramentalmente santificada, pero al mismo tiempo trascendida en su conjunto. En efecto, la sexualidad humana presta a la nupcialidad entre Dios y el mundo el color rojo de la vida, sexo y sangre que circula, pero se lo presta para después transfigurarse muriendo a sí misma, en esa realidad más grande de lo que ella es "misterio". El hombre se la ha prestado a Dios, y Él se la devuelve engrandecida, de tal modo que el hombre ya no puede mirar más hacia su pequeña concepción primera, sino a aquello que Dios le ha devuelto trascendido. El hombre debe vivir la relación sexual en este nuevo ámbito pero esto solo a condición de ser vivido desde los sentimientos de la cruz, donde toda concupiscencia mala es superada mediante el altruismo de la entrega cristiana (Balthasar, 1989). Deben el hombre y la mujer interpretar sus relaciones sexuales como actos que envían inmediatamente al misterio de la "única carne" existente entre Cristo y la Iglesia (Balthasar, 1976). Ágape es la palabra nueva, acuñada por Cristo de manera eminente, que indica el amor de los esposos cristianos y que invade todas las dimensiones de ese amor. Ella indica la expropiación y entrega de sí mismos, en la cual se encuentra la fecundidad personal psíquico-corpórea de Cristo y en la cual cada deseo y cada emisión del semen puramente biológico es inmerso en el acto total de una entrega personal que no se reserva nada para sí (Balthasar, 1991a). Esto trae entonces como consecuencia, que el hombre en el acto sexual puede satisfacer el mandamiento de amar a su mujer como a su propio cuerpo, solo si se da incondicionalmente, reconociendo al igual que Cristo, en el cónyuge, a su propio cuerpo (Balthasar, 1991b). 
La Gracia derramada desde la cruz sobre la dimensión sexual, permite que los esposos cristianos, esperen de Dios, en el encuentro erótico, la rebosante respuesta de su gracia. Su amor, que externamente parece ser agotado en los dos cónyuges, viene a participar secretamente del ilimitado amor del Señor, cuya fecundidad se derrama más allá de las estrecheces humanas. Y eso porque en esta fecundidad del amor de la cruz del Señor se ha revelado la ley del amor Trinitario mismo, que no se agota entre Padre e Hijo, sino que está abierto a un tercero, el Espíritu, al que pertenece de manera especial el amor en Dios. Solo esta participación en la cruz da a la entrega física entre los esposos su última justificación redentora (Balthasar, 1994).

No podría pensarse que por el hecho de que un hijo no llegue como fruto de la relación sexual, ésta no tendría ningún valor y fruto. El hijo es un "alguien" que viene donado, como sobreañadido, y por tanto un matrimonio físicamente infecundo no es por necesidad un matrimonio fracasado e infeliz. Es claro para Balthasar (1979) que, no se puede designar como fin primario del matrimonio la generación de la prole, como se hizo en tiempos antiguos. En el matrimonio contraído entre cristianos se trata primariamente de una radicalización del encuentro personal, no solo en lo que tal encuentro tiene de espiritual, sino también en todo lo que tiene de corporal. Tal radicalización está precisamente en el hecho de hacerse un solo cuerpo en la entrega personal, cuya exclusividad -este hombre, esta mujer- es la forma espacio temporal en que esta entrega se realiza en forma encarnativa.

Es evidente que de la relación marital puede surgir un fruto corpóreo: el hijo, que no pude ser considerado simplemente como casual resultado del acto o, dicho en clave biológica, como la suma de cuanto se ha unido; sino como el producto maravilloso, insospechado e inesperado de su esperanzada entrega, que les viene donado de lo alto. Pero, es necesario reconocer que la aparición del fruto corpóreo no anula o agota ese tercer objetivo, creación de las dos voluntades unidas y desposeídas, del que antes se ha hablado, sino que cuando el hijo se hace presente y está en proceso de desarrollo, asume inexorablemente en su servicio ese amor nupcial de los padres, renovándolo continuamente en lo más profundo. Puede decirse entonces que el hijo es la revelación, la manifestación y la ostentación de ese pacto de amor, que emerge corporal en su existencia propia.

Lo dicho está lejos de plantear una justificación para actos sexuales voluntariamente infecundos -en el sentido físico-. El mismo Balthasar (1990) denuncia la insensatez de la sociedad actual, en que los hombres han partido en dos la unidad del amor humano. El hombre, inventor de la prostitución se resiste a ser padre, y la mujer, movida por ansias feministas rechaza la maternidad, resignándose a un 
acto que deje intacta la distancia corporal y espiritual. Un amor tal, que excluya de su acto la posibilidad o el "peligro" del hijo, no es más un acto incondicionado.

\subsection{Pobreza, castidad y obediencia recuperadas}

Los esposos, en cuanto cristianos, viven una misión difícil, pues por un lado, están llamados a salir del mundo, han sido transformados por la Gracia y puestos en una situación nueva que los ubica en el camino del amor perfecto a Dios y al prójimo, situación y ubicación que les exige igualmente asumir la tarea de dar testimonio en favor de Cristo. Pero, por otro lado, ellos tienen el encargo cultural, recibido desde la creación, y para realizarlo no poseen ya los órdenes originales de la naturaleza, sino los combinados con la caída, a saber: el orden de la propiedad privada y del derecho exigible, la procreación, la libre formación de la opinión personal. El hombre, inmerso en el mundo, no puede escapar a estas modalidades de la naturaleza haciendo como si ellas no le tocaran o como si no fueran vinculantes para él, actuando como si se moviera personalmente en el orden original del paraíso. El cristiano casado tiene así que cumplir tanto la orden cultural, como observar el llamamiento general del amor cristiano que le llama desde el mundo caído al orden de la redención (Balthasar, 1994).

En el desarrollo de su vida cristiana, cada individuo, y por tanto también los esposos cristianos, deben tener en gran aprecio la pobreza cristiana y poner lo que esté de su parte para hacerla eficaz en el mundo. Una tal pobreza evangélica viene entendida por Cristo en una manera más amplia que aquella simplemente material. En la Escritura los pobres a que se llama bienaventurados son aquellos que a falta de cosas propias, disponen de espacio para acoger con gozo a Dios y su mensaje. No es necesario demostrar expresamente que con esta pobreza Cristo entiende también la pobreza real, literal, que es punto de partida y primera condición para aquellos que quieren ser discípulos del maestro. En efecto, si no se comienza con la pobreza material, todo permanece un noble murmullo y no se hace nada (Balthasar, 1966).

El cristiano que desarrolla su vida y misión en el mundo y que por tanto, debe tener necesariamente contacto con el dinero y el poder, puede vivir la actitud de pobreza aprendiendo a ver las cosas con los ojos de Dios, es decir, entendiendo que en el mundo todo aquello que es cosa, que es impersonal, tiene valor en la medida en que está ordenado a la persona, y que todo aquello que cosifica a la persona y la esclaviza no posee ningún valor. Si los cristianos dentro del mundo siguen este criterio, la lucha sostenida entre el hombre y el universo, que 
tiene como fin arrancar del segundo sus más profundos secretos y hacer actuales sus más inimaginables potencialidades, será justa y motivada, pues tendrá como meta la humanización del hombre, pero una humanización trascendente y reconocedora de que el ser humano, en cuanto amado por Dios y hecho criatura nueva en Jesucristo, no puede vivir para la riqueza, el poder la satisfacción o la gloria, pues quien así vive no se conoce a sí mismo, no conoce su lugar en el mundo y no conoce a Aquel que lo ama y redime (Balthasar \& Giussani, 1981).

Los esposos cristianos están llamados a introducirse en las estructuras sociales transformándolas, en cuanto esto es posible, mediante un testimonio concreto de su fe, poniendo lo que son y poseen al servicio de la comunión y de la caridad cristiana. Balthasar (1994), invita a los esposos, a que concreten este ideal en el marco de la Iglesia, poniendo al servicio del desprendido amor cristiano, bienes espirituales y materiales. Para esto, el teólogo suizo remite a la actitud de las primeras comunidades cristianas que liberaron el dinero de su contraposición a Cristo, haciendo de él signo eficaz del amor donante.

En cuanto a castidad, la plena integración del orden de los sexos tal como existía en el paraíso no es más posible en las circunstancias presentes de la humanidad; sin embargo, por la gracia que el Señor ha derramado desde la cruz, se puede hablar con todo derecho de un "matrimonio honorable en todo, de un inmaculado lecho conyugal" ( $\mathrm{Hb} 13,4)$. Pero esto, no de manera automática, sino solo si la unión conyugal que hace del hombre y de la mujer una sola carne, se convierte en signo de la unión definitiva e indisoluble del Señor que se entrega en la cruz con su Esposa la Iglesia. Los cuerpos, por la acción de la cruz, en el matrimonio han sido expropiados, y esto no solo gracias a un cuerpo, sino a un cuerpo dado en sacrificio a otro cuerpo y en el acto de expropiarse y donarse realizan el misterio de la unidad en una sola carne, que comporta también la unidad en un solo espíritu. Si el acto sexual entre los cristianos es vivido según la ley del ágape es casto, pero si no está informado por ese amor de comunión, es prostitución (Balthasar, 1989).

Desde que Cristo con su cruz cambió la historia del mundo y del hombre, y desde cuando concedió al hombre participar de su misterio, el cuerpo cristiano es templo del Espíritu Santo y, por tanto, el comportamiento sexual del cristiano debe ser para el mundo en que vive un testimonio sorprendente, al igual que debe serlo su fe, pues, comportamiento y fe están indestructiblemente unidos, y su comportamiento sexual hace parte de su fe encarnada y creíble (Balthasar, 1972). 
Respecto a la obediencia afirma Balthasar (1979) que una consideración de ésta, que no parta de la cristología, no puede sostenerse. De hecho, la cristología es la forma íntima de la eclesiología y solo en ella se puede establecer la relación existente entre la obediencia de Cristo como cabeza, y de la Iglesia como cuerpo y como miembros.

Es relevante contemplar, cómo el Hijo, aún siendo Dios, no obedece a sí mismo, sino a otro. Si el Hijo fuera obediente en razón de una natural subordinación a Dios Padre, obedeciendo no haría más que su deber, y en esto no aparecería el amor de Dios absolutamente libre. Pero, si él obedece sin motivo, lo hace entonces por puro amor. Algo que ante los ojos de los hombres puede parecer tan extraño, que el mismo Pablo no dudará en calificar de insensato (Balthasar, 1966).

En su extrema obediencia, Jesús objetivamente ha realizado la redención del mundo y ha invitado a los hombres a seguirlo en su camino. Esta invitación general a ir en pos de él saliendo de las estructuras de pecado presentes en el mundo, esta invitación a hacerse su discípulo, a hacerse cristiano, se cumple en el Bautismo como configuración a su muerte. El Bautismo se convierte, por tanto, en acto de obediencia que da el consentimiento a lo que ya era real y objetivo, es un evento que ratifica la libertad que nos ha conseguido Cristo desde la cruz, al romper la cadena que nos sujetaba: el pecado. Por el Bautismo, el cristiano decide entrar en la comunidad de los que han aceptado la redención de Cristo, entra a ser parte de la Iglesia y es en ella donde debe hacer concreto su espíritu de obediencia al Señor. Puede hablarse, por tanto, de una obediencia interna en la Iglesia. En ella, cada uno debe subordinarse obedeciendo a la ley trascendente de unidad que es Cristo, y a quienes él ha puesto como legítimos administradores de sus misterios. El cristiano debe ver en los titulares del ministerio a Cristo, pues ellos han recibido y reciben personal y directamente la gracia y el mandato de Cristo (Balthasar, 1979). Los esposos cristianos, como quienes viven del espíritu de Cristo, experimentan este espíritu de obediencia prestando su adhesión en las situaciones decisivas, a quienes en la Iglesia tienen la función de enseñar, santificar y pastorear, siguiendo a Cristo que se sometió a la voluntad del Padre para redimir al mundo. Pero esto no sólo como imposición vacía de sentido y dada desde el externo, sino como participación gozosa en la obediencia eclesial que reconoce en los pastoreas la presencia de la Palabra de Dios y la actuación de la Gracia de la redención, aun cuando sepa que las cualidades personales de los ministros están lejos de coincidir, a veces más a veces menos, con la dignidad de la misión que ostentan (Balthasar, 1994). 


\section{Matrimonio: vínculo santo contraído por pecadores}

"No tenemos un Sumo Sacerdote incapaz de compartir el peso de nuestras debilidades, sino al contrario, tentado en todo, igual que nosotros" ( $\mathrm{Hb} 4,15)$. Esta expresión muestra al creyente hasta qué punto fue Jesús puesto a prueba. "Él sabe por experiencia lo atractivo que puede resultar el otro camino, el que no es camino de Dios. Sabe lo que significa pender sobre el abismo sostenido únicamente por el hilo de una palabra de Dios" (Balthasar, 1982, p. 33). Más aún, Cristo sin haber cometido pecado sabe lo que es sentirse pecador porque ha experimentado la angustia de la muerte y del abandono de Dios, pues por amor y para alcanzar la redención experimenta en sí mismo el necesario y justo juicio de Dios sobre el mal.

Es cierto que la redención ha sido ya obrada, pero es también cierto que mientras los esposos estén inmersos en este mundo caduco, la unidad, fidelidad y entrega estarán siempre amenazados, pues el pecado sigue ejerciendo su encanto sobre el creyente. Pero el Señor, conocedor de nuestras debilidades, nos ha dejado en su Iglesia las ayudas necesarias a nuestra débil condición. Por eso, el cristiano que quiere vivir a cabalidad su fidelidad y su amor, puede encontrar en la Iglesia los medios que le ayuden a llevar a feliz término aquello a que se comprometió.

Uno de esos medios es el sacramento de la conversión y reconciliación, en que el cristiano encuentra un modelo externo y a la vez inhabitante del Cristo Esposo que está siempre dispuesto a perdonar a su Esposa. El otro es el Derecho, que teniendo en cuenta las actuales condiciones del hombre, quiere ayudarlo, movido por la ley del amor, a llevar a feliz término aquello a que se comprometió, confiado en la fidelidad del Señor.

Los esposos, que en el sacramento del matrimonio se han prometido amor y fidelidad en el Señor, se ven al igual que todos los hombres, acosados por el pecado, pero saben que pueden contar con aquel sacramento que les permite confesar las faltas que han amenazado o quebrantado el pacto nupcial, ya que con ellas no solo han traicionado al otro, sino que también han deslucido lo que en la tierra representan: el amor de Cristo y de la Iglesia. Con la Reconciliación sacramental, el cónyuge no solo alcanza el perdón de Dios y la reconciliación con la Iglesia, sino que es también invitado a vivir comunitariamente la dinámica del perdonar y ser perdonado, juntamente con el llamado a hacerse transparente al otro, a poner al descubierto ante el que es "una sola carne" con él, el propio corazón; es llamado a dejarse ganar por él para Cristo y a ganarlo a él para Cristo. En este mismo contexto, dice Balthasar (1982) que la entrega corporal concretada en 
el acto sexual, que realiza el misterio de ser "una sola carne", debe abrirse a una intimidad recíproca de toda la humanidad de los cónyuges, debe abrirse a una transparencia total del uno hacia al otro, debe realizar a profundidad el concepto del "conocer", con que la Biblia designa el encuentro corporal de los esposos.

\section{Conclusión}

En su teología matrimonial, Balthasar ha sido fiel a las convicciones que envuelven, como un aura, todos sus pensamientos. Su obra es, ante todo, una estética teológica y en su concepto, la forma supereminente de la belleza se da donde existe un amor entregado hasta las últimas consecuencias. De ahí su predilección por la figura del Crucificado y su convicción de que debe ser Él, el punto focal desde donde el discípulo entiende y realiza toda su existencia (Balthasar, 2006). También las dos características, que entiende como fundamentales el teólogo cristiano, se transparentan en su pensamiento teológico sobre el matrimonio: adoración y obediencia (Balthasar, 2001).

Lógicamente, la visión matrimonial de Balthasar, como todo lo humano, es parcial y obedece a la influencia de un modo personal, teológico y teologal de entender el mundo y la fe y debe por tanto enriquecerse y confrontarse con otras visiones, pero indudablemente su propuesta es, desde el siglo XX hasta hoy, una fuente preciosa, no agotada todavía, desde la que es posible seguir bebiendo para mejor comprender nuestra vida cristiana. La que nos ha ofrecido es una teología matrimonial atravesada enteramente por el Evangelio, no solo por su elemento de gracia, sino también por su exigencia existencial. Su lectura nos ofrece una serie de interrogantes que pueden enriquecer el diálogo sobre un tema al que la Iglesia católica y muchos de sus simpatizantes y detractores vuelven los ojos hoy: el matrimonio sacramental.

En primer lugar, invita la lectura de Balthasar, más bien lejano de la neoescolástica, a dialogar sobre el asunto de la materia y la forma del sacramento. Para él la forma fundamental de la Gracia transmitida en el sacramento es siempre Cristo y la materia que ha de ser conformada es el hombre en su situación concreta, como hombre que debe ser incorporado en el Reino de Dios (Balthasar, 1985a). En el caso del matrimonio la forma sería entonces el amor-ágape de Cristo-Iglesia y la materia serían los discípulos, hombre y mujer que se aman. Un buen punto de diálogo sin duda, con la teología sacramental, que considera que la materia y la forma del sacramento del matrimonio deben buscarse en el consentimiento de los cónyuges. 
El interrogante anterior remite a otro, referido, esta vez, a la clase de amor que puede llegar a ser objeto de sacramentalidad. Ciertamente no es cualquier amor, sino uno que pueda en su necesaria maduración psíquica y espiritual ser y llegar a ser cada vez más, un auténtico sacramento de la donación de Cristo por la Iglesia.

Una tercera discusión es propuesta por el mismo Balthasar al hablar de un necesario redimensionamiento del asunto de los fines del matrimonio que la teología pone en el bien de los esposos y la procreación. Afirma el teólogo que una tal distinción de fines se viene abajo cuando se contempla el matrimonio en su fundamentación sacramental. Cuando los esposos cristianos tienen contacto sexual, afirma "esperan siempre de Dios la rebosante respuesta de su gracia y les resulta imposible distinguir entre el sentido y la finalidad del matrimonio" (Balthasar, 1994, p. 182). Cuánto sean inseparables los dos aspectos es evidente, porque el niño no sólo proviene de este amor recíproco, sino que además requiere la permanencia de tal amor para ser y para crecer. Los fines, que a menudo vienen citados separadamente, no son sólo los dos lados inseparables de una misma cosa, sino que son también, en su inseparabilidad, un signo religioso. La fecundidad es no sólo ley de la vida orgánica, sino también ley de la vida espiritual (Balthasar, 1991a).

Un cuarto aspecto para el diálogo, es la pregunta de si puede ser sacramental, en el sentido pleno de la palabra, un matrimonio entre un bautizado y alguien que no cree en Cristo. Ciertamente es una costumbre tolerada por la Iglesia, pero que no deja de plantear serios interrogantes a la esencia misma del sacramento, entendido en la bimilenaria tradición como símbolo de la gracia que se otorga y canal transmisor de la misma.

Un diálogo franco y abierto sobre estos aspectos, procedentes de la teología matrimonial balthasariana, deberá estar siempre iluminado y guiado por el Evangelio, la Tradición y el Magisterio, y debe realizarse con la confianza en la promesa de Cristo que asegura que el "Espíritu de la verdad guiará hasta la verdad completa" (Jn 15,13), por eso con el ancestral método del discernimiento cristiano, debemos, como exhorta San Pablo, examinarlo todo y quedarnos con lo bueno (cfr. 1 Tes. 5,21). 


\section{Referencias}

Balthasar, H. U. V. (1964). Teología de la historia. Madrid: Guadarrama, . (1966) Chi è il cristiano? Brescia: Queriniana. . (1972). Punti fermi. Milano: Rusconi Editore. . (1976). Cattolico. Milano: Jaca Book. . (1979). Saggi teologici IV. Lo Spirito e l'istituzione. Brescia: Morcelliana.

Balthasar, H. U. V. \& Giussani, L. (1981) El compromiso del cristiano en el mundo. Madrid: Encuentro.

Balthasar, H. U. V. (1982) ¿Nos conoce Jesús? ¿Lo conocemos?. Barcelona: Herder. . (1985a). Gloria I. La percepción de la forma. Madrid: Encuentro. . (1985b). Saggi teologici II. Sponsa Verbi. Brescia: Morcelliana. . (1988a). Gloria VI. Antiguo Testamento. Madrid: Encuentro. . 1988b). María hoy. Madrid: Encuentro. . (1989). Gloria VII. Nuevo Testamento. Madrid: Encuentro. . (1990). Teologica II. Vertitá di Dio. Milano: Jaca Book. . (1991a). Saggi teologici V. Homo Creatus est. Brescia: Morcelliana. . (1991b). Nuovi punti fermi. Milano: Jaca Book.

. (1992a). Teodramática II. Las personas del drama: el hombre en Dios. Madrid: Encuentro.

. (1992b). Teologica III. Lo Spirito della verità. Milano: Jaca Book. . (1993). Teodramática III. Las personas del drama: el hombre en Cristo. Madrid: Encuentro.

. (1994) Estados de vida del cristiano. Madrid: Encuentro.

. (2001) Verbum Caro. Madrid: Encuentro.

. (2006). Sólo el amor es digno de fe. Salamanca: Sígueme. 